\title{
Nursing laboratory and critical education of nurses: approaches and distances
}

\author{
Laboratório de enfermagem e a formação crítica de enfermeiros: aproximações e distanciamentos \\ Laboratorio de enfermería y la formación crítica de enfermeros: aproximaciones y distanciamentos
}

\author{
Fatima Maria de Melo Brito', Célia Alves Rozendo', Priscila de Oliveira Cabral Melo' \\ 'Universidade Federal de Alagoas. Maceió, Alagoas, Brazil.
}

'Universidade Federal de Alagoas. Maceió, Alagoas, Brazil.
How to cite this article:
Brito FMM, Rozendo CA, Melo POC. Nursing laboratory and critical education of nurses: approaches and distances.
Rev Bras Enferm [Internet]. 2018;71(Suppl 4):1500-6. [Thematic Issue: Education and teaching in Nursing]
DOI: http://dx.doi.org/10.1590/0034-7167-2017-0339

Submission: 05-15-2017 Approval: 07-22-2017

\section{ABSTRACT}

Objective: to analyze the contribution of the laboratory of nursing to the critical education of nurses. Method: qualitative study, conducted among 18 professors of higher education institutions, being one public and the other private. Data were collected between February and November of 2016 by means of semi-structured interview. To analyze data, it was used a content analysis in the thematic modality. Results: it was observed the emphasis in the technical skills development by propagation of behavior and practices; the creation of bonds between professors and students happens on the limit of good interpersonal relationship; the laboratory of nursing may help the critical reflection about the practice, being a place that allows the learning of ethics. Final considerations: the nurse education, carried out by the laboratory of nursing, have to overcome the emphasis in the uncritical reproduction of practices and to observe the nurse's power to think about the reality in the meaning of its modification.

Descriptors: Nursing Education; Laboratories; Nursing; Nurses; Nursing Professors.

\section{RESUMO}

Objetivo: analisar a contribuição do laboratório de enfermagem para a formação crítica de enfermeiros. Método: estudo qualitativo, realizado com 18 professores de duas instituições de ensino superior, sendo uma pública e a outra privada. Os dados foram coletados no período de fevereiro a novembro de 2016 por meio de entrevista semiestruturada. Para a análise dos dados, adotou-se a análise de conteúdo na modalidade temática. Resultados: observou-se ênfase no desenvolvimento de habilidades técnicas pela reprodução de comportamentos e práticas; a formação de vínculos entre professores e estudantes se dá no limite das boas relações interpessoais; o laboratório de enfermagem pode favorecer a reflexão crítica sobre a prática, sendo espaço que oportuniza o aprendizado da ética. Considerações finais: a formação do enfermeiro, mediada pelo laboratório de enfermagem, necessita superar ênfase na reprodução acrítica de práticas e observar a potência do mesmo para refletir sobre a realidade no sentido de sua transformação.

Descritores: Educação em Enfermagem; Laboratórios; Enfermagem; Enfermeiras e Enfermeiros; Docentes de Enfermagem.

\section{RESUMEN}

Objetivo: analizar la contribución del laboratorio de enfermería a la formación crítica de enfermeros. Método: estudio cualitativo, realizado con 18 profesores de dos instituciones de enseñanza superior, siendo una pública y la otra privada. Los datos fueron recolectados en el período de febrero a noviembre de 2016 por medio de entrevista semiestructurada. Para el análisis de los datos, se adoptó el análisis de contenido en la modalidad temática. Resultados: se observó un énfasis en el desarrollo de habilidades técnicas por la reproducción de comportamientos y prácticas; la formación de vínculos entre profesores y estudiantes se da en el límite de las buenas relaciones interpersonales; el laboratorio de enfermería puede favorecer la reflexión crítica sobre la práctica, siendo espacio que oportuniza el aprendizaje de la ética. Consideraciones finales: la formación del enfermero, mediada por el laboratorio de enfermería, necesita superar énfasis en la reproducción acrítica de prácticas y observar la potencia del mismo para reflexionar sobre la realidad en el sentido de su transformación.

Descriptores: Educación en Enfermería; Laboratorios; Enfermería; Enfermeras y Enfermeros; Docentes de Enfermería. 


\section{INTRODUCTION}

The object of this study is the contribution of the nursing laboratory to critical education of nurses. The education of these professionals assume a continuous teaching-learning relation, in which students and professors meet in many settings. Among them, the Nursing Laboratory (Labenf), necessary place to collective acquirement of theoretical and practical knowledge aimed at the real health needs of the population. In this way, the starting point should always be the concrete reality, which give meaning to the teaching-learning process and to the education of a professional aware, critical, creative and committed to solve individual and collective problems and open to new possibilities of development.

The National Curriculum Guidelines (DCNs) for the Nursing Graduation Course point out that the nurse education has to meet the social needs of health and to agree with the principles and guidelines of the Brazilian Unified Health System (SUS). For that matter, they point out the necessity to observe the teaching be carried out under a critical, reflexive and creative perspective, implying the integration of curricular activities and the use of methodologies that encourage reflection about the social context and reality ${ }^{(1)}$.

The Labenf, as a basic place for the teaching-learning process and the development of many skills required for nursing activity, have to has as purpose to assure the teaching of responsible, ethical and socially committed care. Such teaching improves student's experience that make them to see themselves as citizen and individual, at the same time they see each other also as the same way. This leads to a professor-student relationship that prioritizes the completeness to the practice of nursing care aiming to the future professional commitment with society ${ }^{(2)}$.

Thus, the Labenf must not be a simple place of techniques and procedures training neither of theoretical and practical knowledge reproduction. It must mainly be a setting that allows the approximation to an objective reality, a device for the general education and the teaching-learning process in special, in the prospect of daily rebuilding and resignification of required knowledge for the professional activity. In this way, the objective of this study is the contribution of the nursing laboratory to the critical education of nurses.

\section{The laboratory of nursing and the nurse education.}

In the field of nursing education - either with the purpose of professional education or for health promotion of population - its essential the exchange of different learning and practice for resignification of knowledge, aiming to the change in the teaching-learning process in the pursuit of creating critical, creative and competent individuals for life and work ${ }^{(3)}$. Change the nursing education and professional practice is needed. For this matter, the change must start inside each one as individual and spread in a collaborative movement ${ }^{(4)}$.

Therefore, the nurse education must be based on knowledge required for the professional practice, in which the enhancement of ethical and humanistic dimensions be assured in the development of attitude and values guided into citizenship, with autonomy and solidarity ${ }^{(1)}$.

Thus, "it's essential provide an ambience of reflection to broaden either the care and its teaching, based on the individual attention to each human being, aiming its autonomy and well-being"(5).

As a challenge, its highlighted the articulation between theory and practice in university education and the critical design of teaching laboratories as prerequisites for activities of clinical practice. Such challenges raise the reflection about learning in this place and reflect the need to think about what should and can be changed ${ }^{(6)}$.

Competitiveness and individualism are present in educational settings, as well as in health care. Such aspects dissent from the social and professional meaning of nursing practice. So, rethink the education of the health professor, in particular of the nursing professor, is a basic task, but also a challenge, implying on critical reflection on such education and commitment to the educational action $^{(7)}$. In this same way, it is necessary to rethink the education of nursing undergraduates, especially with regard to the educational experiences that involve the Labenf. Experience that help to develop ethical, supportive and emancipated individuals ${ }^{(8)}$.

\section{OBJECTIVE}

To analyze the contribution of the laboratory of nursing to the critical education of nurses.

\section{METHOD}

\section{Ethical aspects}

The research was approved by Research Ethics Committees of Universidade Federal de Alagoas (UFAL). The Informed Consent (IC), the authorization of concession and use of the interview were signed by the participants. To preserve the anonymity of the participating professors, it was defined to present them as follows: represented by the capital letter $\mathrm{P}$ followed by the capital letter A or B, what indicate the linked institution, followed by a number, which corresponding to the order of their participation in the study.

\section{Theoretical background}

The critical pedagogy of Paulo Freire was adopted is this study. Based on humanist ethical principles of right to life, in objective reality and the practical experiences, this pedagogy defends a process of humanization driven by "dignity, love and reciprocity" that guides the human being in the "pursuit of self-knowledge and about the world "(9). The critical pedagogy is made by alive pedagogical action that owns the universal human ethics and the social reality problematization, by everyday exercise of teaching and learning by listening and speaking, by the approximation and understanding of reality aiming to its change.

\section{Type of Study}

Qualitative, descriptive and exploratory research.

\section{Setting}

The study was conducted in two Higher Education Institutions $(\mathrm{HEl})$, being one public and the other private, located in a capital of Northeast region of Brazil. The research was composed of 18 professors, being 10 from public HEI (A) and 8 from private HEI (B). The approximation with the research 
fields was via contact with the people institutional responsible for the courses (academic units' directors and courses' coordinators), to obtain formal authorization to conduct the study and to contact the professors (by phone and email). The participants were contacted by the researcher and invited to participate in the study. None of the participants refused to participate in nor abandoned the study.

The inclusion criteria were: to be a nurse and professor of the nursing courses of the HEI A and B, to work at these institutions for at least a year, to use the Labenf during development of the subjects they teach. The exclusion criteria were: to be officially away, for any legal motive, in the period of data collection.

\section{Collection and organization of data}

Data were collected from February to November of 2016, in the institutions where the study was conducted, by the researcher and first author of this study. For this, it was held the semi-structured interview guided by a script composed of two parts. The first, with data of participants characterization; the second, with the following interview's trigger questions: "what is your understanding of nursing laboratory?", "How do you think the nursing laboratory contributes to the nurse education?". Interviews were recorded on a cell phone and lasted 33 minutes each one, on average. They were fully transcribed as were being held.

\section{Data analysis}

Data were analyzed using the "content analysis, in the thematic modality, according to proposed steps: pre-analysis, material exploration/codification/analytic description and treatment of results obtained/interpretation"(10). From this analysis, four themes were produced, presented and discussed in following sessions, in accordance with critical pedagogy.

\section{RESULTS}

It was observed the prevalence of female among the participants, being 15 females and 3 males. It is pointed out, in regard to the title, there are doctors only in the HEI A that, being public, urges to qualification stricto sensu, which is both institutional and central requirement for professor career. In the $\mathrm{HEI} B$ there are masters and specialists. The weekly working hours the participants of the study invest in the Labenf ranged between 1 and 8 hours in the HEI A and between 4 and 12 in the HEI B.

The themes produced by the analysis were: 1 ) propagation and repetition of behavior and practices: focus on development of technical skills; 2) bonds creation between teachers and students: at the limit of good interpersonal relationship; 3) the Labenf favoring the reflection on practice; 4) ethical attitude at the Labenf.

\section{Propagation and repetition of behavior and practices: focus on development of technical skills}

It was identified the enhancement of the Labenf as a learning place, with emphasis on the techniques and its training in the development of students' skills. The propagation and repetition were pointed out as important elements for the learning and also as expression of ethical attitude.
[...], the intervention is so important inside the nursing field and [...] requires skills; and these skills are directly connected to this environment where we can work this skills matter [...]. [...] I think fundamental to this matter of student's learning. (PA3)

The student that explores and repeat more, I believe he can assimilate better. [...]. But I realize there is still a lack of student awareness, that he should practice more with the mannequin, that its essential for the [student] to know at the approach to the patient [...]. The laboratory practice provides a better care for the patient later. (PB6)

[...] of extremely importance for the nursing course and for the all of health field that deal with human life [...] can not just come and go straight to put in practice a knowledge with a patient without previous demonstration in laboratory, that that student tries to perform it on a doll, or even, on a colleague. And that he [student] has a better comfort at the time to perform it on the patient. (PB7)

[...] he [student] will practice, he will have the skills, the technique. Its not the same as to perform on the patient. No, it's never the same thing. (PB5)

[...] we work with those models, that the more the student repeat, we demonstrate and then they repeat, the more skills they learn so, when they go to the patient, they will have more skills to practice, despite the insecurity, but they will have more skills. (PA8)

The learning at the Labenf was considered as a possibility of theoretical-practical articulation, of preparation for the effective contact with the person to be cared, of progressive acquirement of knowledge on increasing levels of complexity. It is important to note that there was, also, recognition of a certain mechanism present in the activities developed in the laboratory. In addition, its was observed concerning of the professor to address to reality in an ideological way, what goes on the opposite of critical pedagogy, that has its start point at the concrete reality.

He [student] glimpse in the theory and we can demonstrate the practice in the laboratory. I believe that its a real chance of learning, before he has contact with the patient itself, inside the health care institution in which [...], we can not perform mistakes in front of the patient. [...] its the chance that he [student] to practice and to be become prepared with dolls in a way we be together and following the evolution of this training, of this learning in the laboratory. (PA4)

[...] at the laboratory I can show him [student] from the simplest techniques to the most advanced situations when we begin to encourage them by simulated situations, even with the patient, but with the dolls we can simulate this. (PA10)

[...] the student tends to merely repeat the assistance behavior of the professional. He [student] want to watch the teacher performing, but its because he wants to repeat it. (PB8)

[...] here at the laboratory we provide the ideal. [...] and outside [at the field of practice] they [students] face the real and they are able to [...] merge the real with the ideal. (PB4) 


\section{Bonds creation between teachers and students: at the limit of good interpersonal relationship}

The participants of the study show more proximity and bonds creation with the students, provided by the environment of the Labenf. The smaller number of student, by group, seems to favor this atmosphere, in which are presented the respect to the individuality, the opening up for dialogue and the estimation for the good relationship.

[...] we created a stronger bond with those students that are with us at the laboratory, [...] around 12 students with us at the laboratory. I care for a more equalitarian relationship inside the laboratory. (PB2)

I see [...] a little of the affective side, but the greater focus in my perception, are skills and accomplishment of works, [...]. [...] it does exist the emotional part where you create a bond with these students inside this place [Labenf], during the class. (PB1)

[...] I have a very good relationship with almost all my students [...] it is a more direct thing, I always preferred to call them aside and talk to them [students] when something is not cool [...]. Then, the student I have to be [...] stricter with, the one I have to be more flexible with [...] talk, understand more his moment, [...] not always we will have time for that, and I try as far as possible to have this relationship of seeing them [students] in an individualized way. (PB3)

I believe its a very good relationship, very friendly, I'm always available so they [students] come to clarify their question, I try to be very accessible to the students in this way, very open so they can [...] to be in this possibility of knowledge creation with me. (PA9)

The good interpersonal relationship is estimated to beyond the "obligation", noting creating of bond, affection and concerning for the student condition. This involvement, which is close to a loving and dialogical attitude, gives positive answer from the student, according to the participants.

The relationship between teacher and student, we can have a communication very effective of sincerity [...]. [...]. I, conversely, feel the proximity, from the other side. [...]. The proximity from my own side, even... [...], it must be an obligation, but it's not an obligation to me. I let the things happen in a very natural way... [...]. But, what is more gratifying to me is to feel that my goal, in this way, is being achieved. To not have barriers, to deal with sincerity. (PA2)

[...] I have a good relationship with them [students], I liked to greet them, to hug them, to ask them about how they are. Some of them come [...] a little bit quiet, and some [...] a little bit sleepy, so we became concerned about it because we know a lot of them come from [...], extracurricular internship, sometimes, they have a night duty, many of them have another job not related to nursing, and come a little bit [...] tired, demotivated, but I try to know how they are. [...], I never start a moment of the class unless I try to know how they are. And the fact that I use the touch, the hug, the smile, I believe it's very inspiring, it's something that bring the student closer, of course there is that hierarchy between teacher and student, but I believe that does not interfere in this hierarchy at all, nor in the respect between teacher and student, I believe that brings closer [...]. (PA7)

However, this understanding perspective is not unanimous. For one of the participants the focus of attention should be the result that the student should present toward the development of skills necessary for professional practice.

[...] if my intention is to do my best so that they become increasingly better professionals, I believe that I don't need to concern just about this interpersonal relationship issue. If I could handle these two things at the same time would be great, but I can't. So, my idea is always to demand the most from them, because I have a very steady idea that, to be a good nurse, you have to be a good nursing student, you have to work hard. I believe the students came here to be good professionals [...]. [...], my idea is to establish a respectful relationship, a relationship of fulfilment of our function, me as a teacher and that student as a student, regardless if this will or won't bring a discomfort, I don't care about this currently, what I care about is if that my attitude will bring a positive outcome or not. (PA3)

\section{The Labenf favoring the reflection on the practice}

The reflection on the practice is in the activities at the Labenf, also in the conversation and discussion of work groups that are set up in dynamics planned by study fields. It is noted an effort to come close to reality, to think over it, to develop the critical ability.

[...] I think it is a very rich moment, both for the student and for us, because we are always reflecting our practice, at that moment that we are using the laboratory [...]. (PA9)

[...] I take constantly during the dialogue to bring them to what they will find in the future. [...], as we keep developing this [the reflection on the practice] in the subject, we note how much they [students] also keep developing this critical ability. So I rather believe that the way we have led and brought this question of thinking, of how to act, of how to play, of what is pertinent and what is not in each moment, this criticality I notice is growing from the beginning to the end of the subject. (PA3)

The autonomy of the student was also brought in the statements, as well as the importance of thinking about learning beyond the development of cognitive or technical skills. According to the study participants, the Labenf can be an instrument of approximation to reality, in order to lead the student to reflect critically on situations of practice.

I realize this critical evaluation of the student and this is even greater, more evident, when we go to the hospital. [...]. So it is the moment when they [students] observe that their role has to be unique, that they have to have a posture before that patient, of welcome, of love, and that it is not enough at that moment only to know how to use technique. (PA4)

When we are doing the activities on the mannequin, [...] he [student] always has to reflect that there [in Labenf] he will be doing [simulations] and when he leaves, [will do] on a 
person [...]. We make him think that its not just a mannequin, but there it is a real situation, that he has to see the complete setting of the woman who is exposed there, [...] who is feeling contractions, [...] who is in pain. It's not just the mannequin, it's the practical setting we bring into the lab. So, he's already doing this critical analysis. (PA5)

[...] the moment you are-talking about ethics, privacy, attitude, skill to listen, skill to respond well to the patient, all this is reinforced in the laboratory. So you can do almost anything. If we guide the student to care in a humanized and holistic way in the laboratory, we expect him to act like this when he becomes a professional, or, as a student, when he starts practicing, in the services. (PB6)

It is highlighted the understanding of which is required to prepare the students to face real situations, and that the Labenf provides this training. However, there was also recognized that some learning situations can only be effectively provided through concrete experiences with people. The Labenf being a simulated environment, some aspects in practice are not actualized, for example, the humanization, which is only established in the interaction between human beings.

[...] he [student] has to learn that the patient he is going to take care of is a patient who feels, loves, has basic needs and, above all, needs respect, and if he [student] is not prepared [...] here in this laboratory environment, I believe he will not be fully ready to practice with the human being itself. (PA7)

[...], for example, today the students stated that [...] they experienced things [situations] of contact with the patient, of interpersonal relationship, and observed the patient was afraid, worried, that he cries and doesn't want to do the procedure and these situations of this relationship we just can observe with the human being itself [...]. (PA4)

[...] its a simulated environment and the humanization is given from human being to human being. The simulator is not human. Its a representation of its [...]. I think that [...], in the requirement "humanization", he [student] will only experience it in the flesh when he be taking care of the flesh. (PB8)

\section{Ethical attitudes at the Labenf}

Participants pointed out that, in the Labenf, the students are prepared, progressively, to adopt ethical attitudes. This refers to aspects related mainly to the professional position, such as responsibility for their actions and respect for the person to be cared of.

[...] responsibility [...], the sense of a professional environment you already begin to have from the moment you [student and teacher] get in the laboratory. (PA1)

[...] we try to work every ethical part with them [students], how they should treat another person, that they will repeat when they get close to the patient, [...] the ethical matter we try to get as good as possible [...]. (PA3)

Something that we work hard on and insist on make clear is to respect people. [...] from the approach to the execution of the procedures is an individual and we are not entitled to judge [...] anything. [...] a human being who is there and needs his intervention and that also has to allow his intervention. [...] protect privacy. [...] to avoid inadequate exposure or beyond what is necessary [...]. (PA2)

As such, the Labenf is a proper place to practice professional ethics, considering the training in mannequins as aspect of this practice. The responsibility and commitment in the care of people at the simulation environment could minimize risks during this activity. However, there must be reflection on this perception, since the statements point to a little enlightening perspective of what and how would be the approach and the practice of ethics in this environment.

[...] I think it is also a place to practice professional ethics, so if you are there in this first stage with a mannequin, a model, then you will [...] deal directly with a human being, so I think it's also an instance of learning and is so that we can practice ethics on the student, to practice responsibility and commitment. [...] so I understand that they [students] to already train directly on humans isn't cool, so I use the laboratory a lot, [...] its an opportunity [...] that only lab provides, and I prize the Ethics very much [...]. (PA6)

And when they [students] first experience, [...], and will make a new simulation, the attitude changes. Both the professional attitude of care and ethical attitude. (PB4)

[...] I think we can not notice the ethical education very much. During the practical moment we have with them [students] I try to pass them my ethical perspective; the ethical perspective of a professional, [...] the ethical perspective established, that one legalized [...]. That one that is delivered by the SUS [...] by our nursing council, by the citizenship established. But how he understands, [...] absorb this, I can not judge. (PB8)

\section{DISCUSSION}

The objective of the study was to analyze the contribution of the laboratory of nursing to the critical education of nurses, from the professors' perspective. The results showed four themes that point to approach to and distance from this critical education. The approaches can be noticed by the concern with ethical issues, with creation of bonds and talking to the students, with the possibility of critical reflection on the reality from the practices developed in the Labenf. The distances are observed mainly by the emphasis given to training and the repetition of the activities developed in the Labenf.

Technical demonstration by the professor for subsequent return by the students is still a keynote in the Labenf. The student copies the way he was taught, repeating step by step what he has learned. As the subject of his learning, the student can shape and reproduce it in practice ${ }^{(11)}$. However, it is not enough to repeat procedures and techniques for learning and delivering quality care. It must be critically reflected, along with the student, on the knowledge and doing, placing him as subject that (re)create and (re) define the reality from the needs pointed out by it.

This is even more imperative when we observe that the education "does not favor a humanistic look", prioritizing 
procedures, technical and mechanical practice in detriment of "patients" needs"(11). The technical-scientific education goes beyond simple training to use technology and technological procedures. Thus, it is important to think critically to choose the technique and its use ${ }^{(12)}$.

The required education for the transformative practices will occur from the critical reflection on the practice. It is fundamental to think the education over, both of professionals and educators, so that they be able to reflect on their practice and to commit themselves to the inductive and productive action of changes. Professional identity and autonomy are being shaped based on the emancipatory practices ${ }^{(7)}$.

An important part of this education lies in the teacher-student interaction, in which "dialogue seals the relationship" between them, being "a permanent tension between authority and free$\mathrm{dom}^{\prime \prime(13)}$. This tension can be worked on through the dialogue that fosters critical thinking, problematizes and respects differences and embraces diversity. However, without ignoring the roles played by many individuals of the educational processes. A relevant aspect to be considered is the commitment to the humanization, should be taken over and encouraged by the educators ${ }^{(11)}$.

Professor and student's attitude in educational relationship should be dialogic, frank, curious and inquisitive. In pursuit of knowledge, the more you practice your curiosity, the more critical and epistemological it becomes, bringing on "imagination, intuition, emotions, ability to predict and to compare" ${ }^{\prime \prime 14)}$. It is not enough to have a good interpersonal relationship, skills and affable and "polite". It is important that it really be dialogical, respectful to different autonomies and responsibilities and, above all, based on emancipatory perspective.

In the dialogical relationship, the act of teach complete with the act of learn. Both acts just happen when the critical thinking of the educator does not interrupt the ability of the learner to think critically. It would be better if the critical thinking of the educator would dive into the curiosity of the learner ${ }^{(15-16)}$. The questioning of reality is central in this setting. Nursing education that becomes questioning constitutes a process of awareness and dialogue created between educators and learners to transform them into people aware of themselves and of their role in history and in the world ${ }^{(17)}$.

Considering that critical education must foster criticality, students, curious to discover the "lived world", must "face it and change it"(11). The "undergraduate nursing programs should receive investment in the training of graduates with criticalpolitical competence ${ }^{\prime(6)}$. Nursing teachers should foster the development of these competences during the practical activities in the Labenf, leading students to critically reflect not only on the technical implications of their practice but also on the political implications.

The Labenf, as a mediator of nurses' education, should be considered as a place for (re) creation of a critical practice, not just as a space of reproduction and repetition of mechanically established practices. It means to think in action as praxis, which implies action and reflection on the world to change it ${ }^{(11)}$.

Following this idea, ethical is the central element of praxis. However, the emphasis on a scientific and technical education, instead of insert ethics as basic practice, highlights it as subject.
That may explain why professors and students don't realize naturally and clearly the ethics' essentiality ${ }^{(2)}$.

Results from integrative review of studies carried out in country of different continents about ethical decision-making in nursing showed that nurses have to make ethical decisions daily. The attitude the nurses have and the response they give to ethical problems may vary, depending on their personal features, principles, experiences, and professional competence ${ }^{(18)}$.

Education represents development, and not training. There is no human development outside ethics ${ }^{(19)}$. In this way, the Labenf can contribute to a critical education of nurses and to their preparation regarding ethical decision-making. On the one hand, enabling activities simulation, reflection and discussion about ethical situations; on the other, including the ethical principles in all activities done.

It is important to highlight the responsibility of educational institutions to develop nurses capable of acting according to ethical precepts of the profession and practice of citizenship, of acting in a critical and positive way in health system ${ }^{(2)}$.

\section{Study limitations}

The main limitation was don't explore some set of themes the interview brought up, such as: the teaching-learning process and use of technology, the challenges and possibilities, feelings and emotions brought on by work, all in the Labenf. Such set of themes may be the aim of further discussion and future publications.

\section{Contributions to Nursing}

Contributions of this study to nursing focus on the following points: 1) add knowledge regarding discussion about critical education of nurses, fundamental to develop the profession and to contribute to change the social reality; 2) point out the nursing laboratory as important place of education, as mediator of teaching-learning process and, above all, as place of (re)creation and (re)signification of knowledge and practices essential to professional activity responsible, ethical and socially committed.

\section{FINAL CONSIDERATIONS}

The results indicate the Labenf as an importance place of teaching-learning for the critical education of nurses, with approaches and distances to this education. Although it is still focused on to develop technical skills, it was observed concern for bonds creation between educators and students, as well as for reflection on practice and for fostering ethical attitudes.

The Labenf, as a place that promotes critical education, has to be seen beyond its essential aspects that favor and make it possible to develop technical skills. Simulation, the main strategy used in the Labenf, more than an attempt to train and replicate a context or ideal situation, should be a change to (re)think and (re)create the real situation. The questioning is essential to (re) signify the reality and the dialogue, fundamental to give sense to the relationship between the individuals that make up the processes of development that are intended to be life-changing.

As a fundamental place for nurse education, the Labenf, the closer to reality it is, more critical it becomes and the more 
willing to contribute to education of professionals capable of practicing in reality in order to their change. Conversely, the further from reality it is, emphasizing the ideal, the less critical it becomes and more willing to develop uncritical professionals, disposed to reproduce the status quo. Due to the fact the activities practiced in the Labenf promote education of nurses, it has to overcome the emphasis on uncritical reproduction of knowledge and practices, noticing the important role of the Labenf as a place to reflect on and to create a sense of reality to be changed.

\section{REFERENCES}

1. Brasil. Conselho Nacional de Educação. Câmara de Educação Superior. Institui Diretrizes Curriculares Nacionais do Curso de Graduação em Enfermagem. Resolução CNE/CES n. 3 de 7 de novembro de 2001 [Internet]. Diário Oficial da República Federativa do Brasil, Brasília, DF, 9 nov. 2001[cited 2017 Apr 18]. Available from: http://portal.mec.gov.br/cne/arquivos/pdf/CES03.pdf

2. Kloh D, Lima MM, Reibnitz KS. Compromisso ético-social na proposta pedagógica da formação em enfermagem. Texto Contexto Enferm[Internet]. 2014[cited 2017 Apr 18];23(2):484-91. Available from: http://www.scielo.br/pdf/tce/v23n2/pt_0104-0707tce-23-02-00484.pdf

3. Gottems LBD, Alvarez AM, Almeida LMWS. Educação em enfermagem: qualidade, inovação e responsabilidade. Rev Bras Enferm [Internet]. 2014 [cited 2015 Jun 24];67(4):499-500. Available from: http://www.scielo.br/pdf/reben/v67n4/0034-7167reben-67-04-0499.pdf

4. Becerril LC. O humanismo na formação e prática da enfermagem: uma esperança transformadora. Texto Contexto Enferm[Internet]. 2016[cited 2016 Dec 28];25(1):1-2. Available from: http://www.scielo.br/pdf/tce/v25n1/pt_0104-0707-tce-25-01-editorial.pdf

5. Piexak DR, Backes DS, Santos SSC. Nursing care in the perspective of complexity for nursing professor nurses. Rev Gaúcha Enferm [Internet]. 2013 [cited 2016 Nov 17];34(2):46-53. Available from: http://www.scielo.br/pdf/rgenf/v34n2/v34n2a06.pdf

6. Trevisan DD, Testi CV, Carmona EV, Silva EM. Formação acadêmica e a prática profissional de enfermagem: interfaces para reflexão. Rev Baiana Saúde Pública [Internet]. 2014 [cited 2016 Nov 16];38(1):155-62. Available from: http://inseer.ibict.br/rbsp/index.php/ rbsp/article/viewFile/737/pdf_472

7. Araújo VABT, Gebran RA, Barros HF. Formação e prática de docentes de um curso de graduação em enfermagem. Acta Sci Educ[Internet]. 2016 [cited 2016 Nov 27];38(1):69-79. Available from: http://periodicos.uem.br/ojs/index.php/ActaSciEduc/article/ view/23180

8. Coelho MMF, Miranda KCL. Educação para emancipação dos sujeitos: reflexões sobre a prática educativa de enfermeiros. Rev Enferm Cent O Min[Internet]. 2015 [cited 2016 Jan 04];5(2):1714-21. Available from: http://www.seer.ufsj.edu.br/index.php/recom/ article/view/499/872

9. Pretto FL, Zitkoski JJ. Por uma educação humanizadora: um diálogo entre Paulo Freire e Erich Fromm. Rev Dech[Internet]. 2016[cited 2017 Jan 03];17(29):46-65. Available from: http://revistas.fw.uri.br/index.php/revistadech/article/view/2225/2183

10. Minayo MCS. O Desafio do Conhecimento: pesquisa qualitativa em saúde. 14. ed. São Paulo: Hucitec, 2014.

11. Ribeiro MP. Por uma pedagogia crítica. Entrevista [Internet]. 2016 [cited 2017 Feb 22];23(2):522-47. Available from: http://www. seer.ufu.br/index.php/emrevista/article/viewFile/36500/19253

12. Freire P. Pedagogia da indignação: cartas pedagógicas e outros escritos [Internet]. 2000 [cited 2017 Mar 12]. Available from: http:// www.plataforma.redesan.ufrgs.br/biblioteca/pdf_bib.php?COD_ARQUIVO $=17339$

13. Shor I, Freire P. Medo e ousadia: o cotidiano do professor. Rio de Janeiro: Paz e Terra, 1986.

14. Freire P. Pedagogia da autonomia: saberes necessários à prática educativa. 25. ed. São Paulo: Paz e Terra, 1996.

15. Freire P. Pedagogia da esperança: um reencontro com a pedagogia do oprimido [Internet]. Rio de Janeiro: Paz e Terra; 1992 [cited 2017 Mar 12]. Available from: http://www.dhnet.org.br/direitos/militantes/paulofreire/paulo_freire_pedagogia_da_esperanca.pdf

16. Santos TR, Gros JO. Professor ideal segundo as proposições de Paulo Freire. Unibrasil. Cadernos da Escola de Educação e Humanidades[Internet]. 2014 [cited 2017 Feb 09]. p.63-80. Available from: http://revistas.facbrasil.edu.br/cadernoseducacao/ index.php/educacao/article/viewFile/43/41

17. Rozendo CA, Salas AS, Cameron B. Problematizing in nursing education: Freire's contribution to transformative practice. Nurse Educ Today[Internet]. 2017 [cited 2016 Mar 25];51:120-3. Available from: http://www.dx.doi.org/10.1016/j.nedt.2016.08.009

18. Nora CRD, Deodato S, Vieira MMS, Zoboli ELCP. Elements and strategies for ethical decision-making in nursing. Texto Contexto Enferm [Internet]. 2016[cited 2017 Mar 27];25(2). Available from: http://www.scielo.br/pdf/tce/v25n2/pt_0104-0707-tce-25-02-4500014.pdf

19. Freire P. Pedagogia dos sonhos possíveis. São Paulo. Editora Unesp, 2001. 